PUHEENJOHTAJAN KATSAUS

\title{
Puheenjohtajan katsaus vuoteen 2019
}

\author{
Elina Late \\ Tampereen yliopisto \\ elina.late@tuni.fi \\ https://orcid.org/0000-0002-3232-1365
}

Avainsanat: informaatiotutkimus; seminaarit; tieteellinen julkaisutoiminta; tieteelliset seurat

Sain ilokseni toimia Informaatiotutkimuksen yhdistyksen puheenjohtajana vuonna 2019. Ensimmäinen vuosi puheenjohtajana oli kiinnostava ja opettavainen. Yhdistyksellämme on pitkät ja myös toimivat perinteet, jotka takaavat ja turvaavat yhdistyksen vuosittaisen toiminnan. Sain myös hyvän perehdytyksen puheenjohtajan tehtäviin Noora Hirvoselta, joka toimi yhdistyksen Artikkeli on lisensoitu Creative Commons Nimeä-EiKaupallinen-JaaSamoin 4.o Kansainvälinen -lisenssillä Pysyvä osoite: https://doi.org/10.23978/inf.90666 
puheenjohtajana vuodet 2017 ja 2018. Aktiivinen hallitus on ehdoton edellytys pienelle yhdistykselle, jossa suurin osa työstä tehdään vapaaehtoisvoimin. Hallituksessa vuonna 2019 toimivat Tuulikki Alamettälä (sihteeri), Heidi Enwald, Kristina Eriksson-Backa (vara pj), Ari Haasio, Anu Ojaranta, Topias Mattinen (opiskelijaedustaja) ja Anna Suorsa (taloudenhoitaja). Varajäseninä toimivat Noora Hirvonen, Hilda Ruokolainen ja Jarmo Saarti.

Vuonna 2019 Informaatiotutkimuksen yhdistyksen toiminta oli aktiivista ja saimme juhlia yhdistyksen 40. juhlavuotta. Seuran toiminta on vakiintunut vuosien saatossa kevät- ja syysseminaarien ympärille. Seminaarien yhteydessä pidetään myös sääntömääräiset kokoukset. Näin tapahtui myös vuonna 2019.

Kevätseminaari 2019 järjestettiin Helsingissä tieteiden talolla yhteistyössä Tiedon tähden tiedelehtikiertueen kanssa. Tiedekustantajien liitto rahoitti ja organisoi tiedelehtikiertueen ${ }^{1}$, joka vieraili useilla Suomen korkeakoulupaikkakunnilla tekemässä näkyväksi suomalaista tiedejulkaisemista. Informaatiotutkimuksen yhdistys oli aktiivisesti mukana tiedelehtikiertueen ideoinnissa ja järjestelyissä. Yhdistyksen ja tiedelehtikiertueen yhteisessä kevätseminaarissa käsiteltiin erityisesti kotimaiseen tieteelliseen julkaisemiseen liittyviä teemoja. Professori emeritus Seppo Hentilä Suomalaisesta Tiedeakatemiasta pohti inspiroivasti tutkimuksen, kirjoittamisen ja julkaisemisen merkitystä tieteellisessä ajatellussa. Informaatiotutkimus-lehden toimitussihteeri Harri Ollikainen jakoi satoa Tiedekustantajien liiton järjestämästä koulutuksesta, jossa vuosittain perehdytään tiedekustantamisen maailmaan. Seminaarissa Heidi Enwald ja Esko Clarke Sario kertoivat kokemuksiaan tiedelehtikiertueelta ja Mikael Laakso (Hanken Svenska Handelshögskolan) esitteli avointa vertaisarviointia tutkineen hankkeen tuloksia. Hankkeen loppuraportti on luettavissa TSV:n julkaisusarjassa².

Seminaarin jälkeen järjestetyssä kevätkokouksessa käsiteltiin yhdistyksen vuoden 2018 toimintakertomus ja suunniteltiin loppuvuoden toimintaa niin lehden kuin seminaarienkin osalta.

Vuoden 2019 syysseminaari oli yhdistyksen toiminnan 40-vuotis juhlaseminaari. Informaatiotutkimuksen yhdistys perustettiin Tampereella joulukuussa 1979. Yhdistyksen perustamiskirjan allekirjoittivat 14 alalla toimivaa tutkijaa, opiskelijaa ja asiantuntijaa. Syysseminaarissa saimme kuulla kattavan paketin Informaatiotutkimuksen yhdistyksen toiminnasta sen perustamisvuosista tähän päivään.

\footnotetext{
1 https://tiedekustantajat.fi/tiedotteet/tiedon-tahden-kotimaiset-tiedelehdet-kiertueelle-tiedekustantajien-tuella/ 


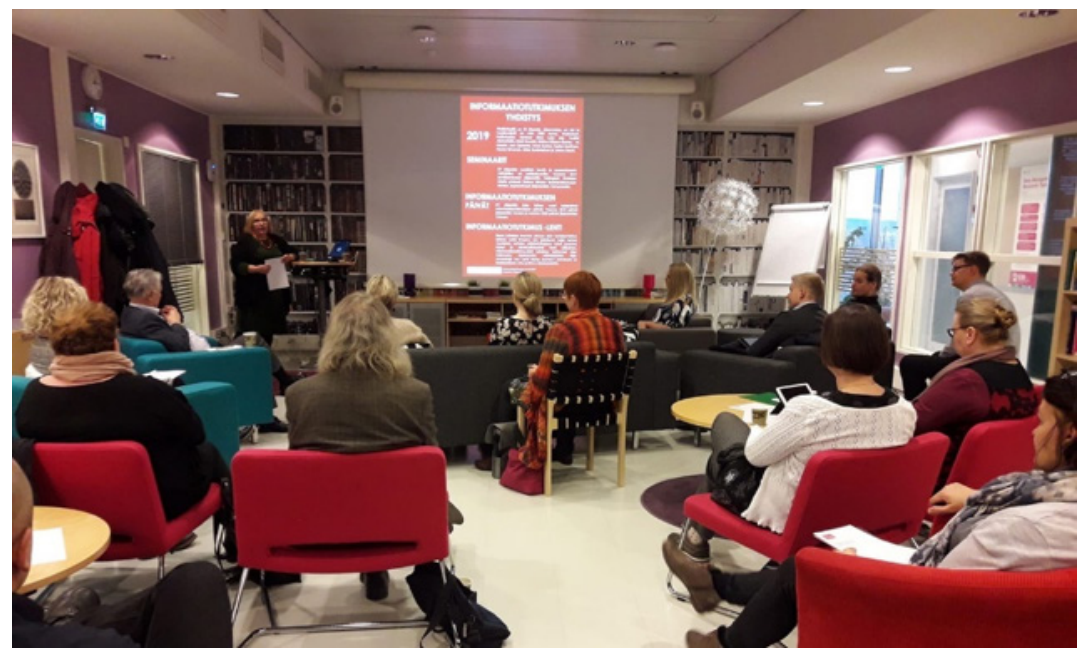

Kuva 1: Maria Forsman ja syysseminaarin yleisöä. (Kuva: Heidi Enwald)

Seminaarin aloitti Maria Forsman, yksi yhdistyksen perustajajäsenistä, joka kertoi 40-vuoden takaisista tapahtumista ja yhdistyksen alkuvuosista. Marian esitys on luettavissa myös Informaatiotutkimus-lehdestä3 ${ }^{3}$ Ohjelmaa jatkoi Heidi Enwald Oulun yliopistosta. Heidi toimi yhdistyksen puheenjohtajana vuosina 2015-2016 ja kertoi esityksessään, mitä tieteellisen seuran puheenjohtajan tehtävään kuuluu. Tuomas Harviainen (Tampereen yliopisto) avasi tieteellisen seuran merkitystä tutkijan näkökulmasta. Seminaarin loppuaika käytettiin lehden asioihin. Lehden entinen päätoimittaja Jarmo Saarti (Itä-Suomen yliopisto) kertoi Informaatiotutkimus-lehden digitalisoimisesta ja päätoimittaja Susanna Nykyri (Tampereen yliopisto) lehden nykytilasta. Susanna sai myös esitellä lehden uuden päätoimittajan Mikael Laakson, joka aloitti tehtävässään vuoden 2020 alussa.

Syyskokouksessa valittiin yhdistyksen uusi hallitus, toimihenkilöt sekä puheenjohtaja. Yhdistyksen sihteerinä viimeiset kaksi vuotta toiminut Tuulikki Alamettälä luovutti tehtävänsä Laura Korkeamäelle. Taloudenhoitajana jatkaa Anna Suorsa, puheenjohtajana allekirjoittanut sekä varapuheenjohtajana Kristina Eriksson-Backa. Näiden lisäksi yhdistyksen hallituksessa toimivat vuonna 2020 Tuulikki Alamettälä, Heidi Enwald, Ari Haasio, Anu Ojaranta ja Topias Mattinen (opiskelijaedustaja). Varajäseniksi valittiin Noora Hirvonen, Hilda Ruokolainen ja Susanna Nykyri. 
Tällä kokoonpanolla on hyvä lähteä suunnittelemaan uutta toimintaa vuodelle 2020. Suomea, Eurooppaa ja koko maailmaa kohdannut koronavirus ja sen aiheuttama kriisi vaikuttaa myös Informaatiotutkimuksen yhdistyksen toimintaan. Jouduimme valitettavasti perumaan yhdistyksen kevätseminaarin, joka oli suunniteltu pidettäväksi Seinäjoen ammattikorkeakoululla. Toivottavasti pystymme järjestämään Informaatiotutkimuksen päivät loppuvuodesta Oulun yliopistolla. Informaatiotutkimuksen päiville odotamme perinteen mukaan kiinnostavia esityksiä ja paljon yleisöä. Tervetuloa mukaan!

ITY ry:n puheenjohtaja

Elina Late

\section{INFORMAATIOTUTKIMUKSEN YHDISTYS}

\section{vuosibudjetti on noin 7000 eurod. Yhdistyksen hallituksessa toimivat Elina Late (pj). Tuulikki Alamettälä, Heidi Enwald, Kristina Eriksson-Backa, Ari Haasio, Anu Ojaranta, Anna Suorsa, Topias Mattinen, Noora Hirvonen, Hilda Ruokolainen ja Jarmo Saarti.}

\section{SEMINAARIT}

ITY järjestää vuosittain kevät- ja syysseminaarin vaihdellen eri paikkakunnilla. Vuonna 2019 kevätseminaari järjestettiin Helsingissä Tieteiden talolla yhdessä Tieteen tähden tiedelehtikiertueen kanssa. 40-v juhlasyysseminaari järjestettiin Tampereella.

\section{INFORMAATIOTUTKIMUKSEN}

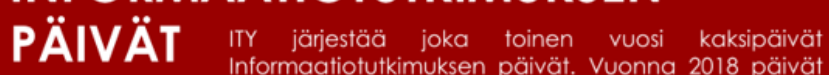
Informaatiotutkimuksen päivät. Vuonna 2018 päivät järjestettiin Turussa ja vuonna 2020 päivät järjestetään Oulussa.

\section{INFORMAATIOTUTKIMUS-LEHTI}

Seura julkaisee Suomen ainoaa alan vertaisarvioituc lehteä. Lehti ilmestyy OA julkaisuna neljä kertaa vuodessa. Lehden päätoimittajana toimi Susanna Nykyri ja toimitussihteerinä Harri Ollikainen. Informaatiotutkimus-lehti julkaisee kattavasti alan tutkimusta, tapahtumia, väitöslektioita, kirjaarvosteluja jne. Lehti löytyy journal.fi palvelusta ja indeksoidaan Arto ja DOAJ-tietokantoihin.

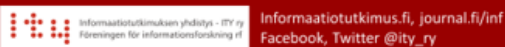

Kuva 2: Informaatiotutkimuksen yhdistys vuonna 2019 